Article

\title{
More Than Open Space! The Case for Green Infrastructure Teaching in Planning Curricula
}

\author{
Andrea I. Frank ${ }^{1, *}$, Andrew Flynn ${ }^{2}$, Nick Hacking ${ }^{2}$ and Christopher Silver ${ }^{3}$ \\ ${ }^{1}$ School of Geography, Earth and Environmental Sciences, University of Birmingham, Birmingham, B15 2TT, UK; \\ E-Mail: a.i.frank@bham.ac.uk \\ 2 School of Geography and Planning, Cardiff University, Cardiff, CF10 3WA, UK; E-Mails: flynnac@cardiff.ac.uk (A.F.), \\ hackingn@cardiff.ac.uk (N.H.) \\ ${ }^{3}$ College of Design, Construction and Planning, University of Florida, Gainesville, FL 32611, USA; E-Mail: silver2@ufl.edu \\ * Corresponding author
}

Submitted: 29 July 2020 | Accepted: 10 September 2020 | Published: 26 January 2021

\begin{abstract}
Since the mid-1990s, the concept of Green Infrastructure (GI) has been gaining traction in fields such as ecology and forestry, (landscape) architecture, environmental and hydrological engineering, public health as well as urban and regional planning. Definitions and aims ascribed to GI vary. Yet, agreement broadly exists on Gl's ability to contribute to sustainability by means of supporting, for example, biodiversity, human and animal health, and storm water management as well as mitigating urban heat island effects. Given an acknowledged role of planners in delivering sustainable cities and towns, professional bodies have highlighted the need for spatial planners to understand and implement GI. This raises questions of what sort of GI knowledge planners may require and moreover by whom and how GI knowledge and competencies may be conveyed? Examining knowledge and skills needs vis-à-vis Gl education opportunities indicates a provision reliant primarily on continued professional education and limited ad hoc opportunities in Higher Education. The resulting knowledge base appears fragmented with limited theoretical foundations leading the authors to argue that a systematic inclusion of green infrastructure knowledges in initial planning education is needed to promote and aid effective GI implementation.
\end{abstract}

\section{Keywords}

curricula; green infrastructure; higher education; planning profession; spatial planning

\section{Issue}

This article is part of the issue "Urban Planning and Green Infrastructure" edited by Paul Osmond (University of New South Wales, Australia) and Sara Wilkinson (University of Technology Sydney, Australia).

(C) 2021 by the authors; licensee Cogitatio (Lisbon, Portugal). This article is licensed under a Creative Commons Attribution 4.0 International License (CC BY).

\section{Introduction}

Since the mid-1990s, the concept of green infrastructure (GI) has gained increasing traction in built and natural environment associated fields. These include ecology, forestry, (landscape) architecture, environmental and hydrological engineering, public health, and urban and regional planning. Depending on subject and geographical context, the definition of what constitutes $\mathrm{Gl}$ varies as do the benefits perceived from GI (Benedict \& McMahon, 2001). For example, American Rivers, a US based conservation organization, defines GI as "an approach to water management that protects, restores, or mimics the natural water cycle" (American Rivers, n.d.). As such it offers a cost-efficient approach to meet the requirements of the national Clean Water Act (Emmett Environmental Law \& Policy Clinic and the Environmental Policy Initiative, 2014). The Pennsylvania Land Trust, meanwhile, suggests that Gl acts as tool for smart growth and conservation (Benedict \& McMahon, 2006). Moving beyond water and land management, the European Commission (2020) stresses the multifunctionality of $\mathrm{Gl}$ and its value in terms of ecosystems services such as air quality enhancement, climate change mitigation and adaptation, and 
citizens' health and wellbeing by providing leisure spaces. Differing definitions aside, however, GI is consistently conceived as a strategically planned network of natural and semi-natural areas. There is broad agreement that $\mathrm{Gl}$ offers tangible benefits for society and the environment through its contributions to a sustainability transition of urban and peri-urban areas (e.g., Tzoulas et al., 2007). In fact, Benedict and McMahon (2002), coming from a landscape architecture and planning background, go as far as labelling GI as a life support system for communities, which not only contributes to but is essential for environmental and economic sustainability.

Given planners' role in delivering sustainable development (e.g., Royal Town Planning Institute, 2015; UN Habitat, 2009;), they are seen to hold a key role-alongside landscape architects and environmental engineers-in developing, designing and implementing $\mathrm{GI}$ on the ground. In the UK, the Royal Town Planning Institute's briefing explicitly notes that "the importance for planners to understand and apply a green infrastructure approach has never been greater" (Royal Town Planning Institute, 2013, p. 2). Green infrastructure and its material manifestation as in green roofs and walls, green belts, parks or rain gardens and so forth are more and more integrated in statutory as well as informal planning instruments such as zoning plans, resiliency and climate change mitigation strategies at city level, in strategic spatial plans, or land use plans (e.g., Hansen, Rall, Chapman, Rolf, \& Pauleit, 2017). The coordinating role identified for the planning profession implies a need for substantial (new) knowledge and skills in regional design and policy measures that promote GI development. This also includes knowledge of how to effectively work in partnership with different local and regional actors across disciplinary and administrative boundaries (Hansmann et al., 2016) and engage with communities (Zuniga-Teran et al., 2020).

Much literature on GI consists thus far of a proliferation of reports from industry (e.g., UK Green Building Council, 2015), non-profit organizations (The Earth Genome, 2016), and government and supragovernmental bodies (e.g., Environmental Protection Agency, 2014; European Commission, 2016; Natural England, 2009) promoting the idea of building, enhancing, investing and maintaining green infrastructure. Themes expressed by these documents are mirrored by built environment professional bodies (in planning, landscape architecture or engineering) and research projects that offer practical guidance and training for practitioners on $\mathrm{Gl}$ design, valuation and implementation (e.g., American Planning Association, 2007; Australian Institute of Landscape Architects, 2015; Hansen et al., 2017; Royal Town Planning Institute, 2013; UK Green Building Council, 2015). Two different strands of GI practice display prominence (although within and between these, different perspectives exist): An emphasis on biodiversity and ecology of habitat networks and a technological and engineering focus, for example, green roof design or sustainable drainage systems. In addition, several comprehensive overview texts such as the Handbook on Green Infrastructure (Sinnett, Smith, \& Burgess, 2015), the Routledge Handbook of Ecosystem Services (Potschin, Haines-Young, Fish, \& Kerry Turner, 2016) and Green Infrastructure Planning: Reintegrating Landscape in Urban Planning (Mell, 2019) have been published. Interestingly, while Sinnett et al. (2015) make reference to the potential educational benefits afforded by GI such as informing the public on nature, biodiversity, and also the need of providing skills for those caring for green infrastructure, the discussion of the type of Gl education required for professionals such as planners, engineers or urban administrators remains sparse. Manley (as cited in Sinnett et al., 2015) alludes to the need of educating professionals. However, her contribution focuses on designing and implementing inclusive environments primarily, while emphasizing secondarily that this also applies to parks and green public spaces. More recently, training needs in operationalising $\mathrm{Gl}$ approaches and instilling multi-criteria GI thinking that overcome silomentalities were identified by Lennon, Scott, Collier, and Foley (2016), and Meerow and Newell (2017).

Accepting the relevance of $\mathrm{Gl}$ to planning sustainable cities and focusing on English-language provision, this article critically queries the training and educational needs for the planning profession that may arise from the growing $\mathrm{Gl}$ discourse and considers how these might be addressed. In terms of education for planning, both university level programmes and continued professional development contribute to address skill and knowledge needs. Continued professional development tends to focus on praxis and technical issues shunning less tangible but no less important conceptual and theoretical aspects. The latter tend to be a prerogative of university level education.

In planning education curricula, GI may be perceived by some as old wine in a new bottle-merely requiring a relabelling of pre-existing topics (e.g., open space planning and protection) which have been a part of planning education for decades to reflect new en vogue terminology. In some institutions, in fact, planning courses were first started in landscape architecture faculties (Silver, 2018). Others-including the authors of this article-consider designing, planning and implementing $\mathrm{Gl}$ a sufficiently distinct knowledge field that warrants a more explicit inclusion in planning education. The article develops this rationale in three sections. First, examining the relationship between green/open space and green infrastructure from a planning perspective reveals similarities and differences in terms of knowledge needs. Second, the article then presents findings from a review of GI knowledge provision. Third, outcomes suggest that a more systematic and integrated, interdisciplinary coverage of $\mathrm{Gl}$ at degree level would be of merit to progress a sustainability transition by working more effectively toward implementing Sustainable Development Goals of the UN (UN, 2015) and the New 
Urban Agenda (UN Habitat, 2017), which was ratified by the UN Conference on Housing and Sustainable Urban Development (Habitat III).

\section{Green Infrastructure Vis-à-Vis Green/Open Space Planning}

Spatial, urban and regional planning always has had links to or included open space planning, be it for 'green spaces' such as urban parks with largely unsealed, permeable surfaces consisting of grass, shrubs and trees, or 'grey spaces' such as plazas and squares with hard, impermeable surfaces (Swanwick, Dunnett, \& Woolley, 2003). At a regional scale, planning and land management also includes landscape and resource protection (e.g., aquafers; minerals and agricultural land) and the structuring of urbanized areas through green belts and green wedges. Historically, there were recreational and aesthetic considerations (Olmsted, 1870, pp. 24-25) and environmental considerations guiding such work (Walmsley, 1995, p. 90). Ebenezer Howard's garden city and later movements promoting public parks for the health of urban populations attest that planners had a considerable awareness of the importance of open green space as a factor for quality of life.

The term GI was used first by Hauserman (1995) and Walmsley (1995) in the context of regional greenway network planning and urban neighbourhood scale greening concepts. In parallel, Ahern (1995)-a landscape architect-coined the term 'ecological infrastructure' emphasising the contribution of vegetated areas to ecological, hydrological and physical processes facilitating life. This connotation of GI promotes an ecosystem services lens to human wellbeing (MEA, 2005) and suggests a reframing of human-environment interactions (Chaudhary, McGregor, Houston, \& Chettri, 2015) distinct from 19th and early 20th century values attached to green space. Gl then gained further currency as evidenced by an increase in publications post turn of the Millennium (see Tzoulas et al., 2007). Publications on GI focus on a variety of aspects and are lodged in disciplines ranging from ecology and forestry to hydrology and environmental engineering and other built environment professions such as architecture, landscape architecture and planning. Additional fields such as sustainability science and public health are also entering the GI discourse. As different professions adopted the term, its meaning evolved (Mell, 2019) to encompass inter alia ecological as well as hydrological systems (green and blue space; cf. Liu, Chen, \& Peng, 2014; Stovin, Jorgensen, \& Clayden, 2008). Furthermore, from early on the emerging GI knowledge and practice was often linked to institutional understandings of planning systems as illustrated here for Sweden:

It...seems necessary to upgrade urban space, preferably as a coherent planning entity [called] green infrastructure, and accord it the same status as other physical urban structure, e.g., buildings and highways. Only then would urban planners widen their attention to the manifold functions of urban green spaces. (Sandström, 2002, p. 380)

Overall, GI tends to refer to strategically planned and created regional-scale greenways or networks of connected green spaces. Gl is to counter landscape fragmentation and the destruction of biotope/habitat functionality that often results from continued, unstructured settlement growth and urban sprawl. A key difference to standard open space or landscape planning is that GI moves beyond merely protecting and preserving natural areas (cf. Lennon et al., 2016); it entails the purposeful re-creation of multifunctional, open and green spaces and/or the improvement of the qualities of existing ones. This quality improvement of green spaces often emphasises the enhancement of the ecological, social, economic, and cultural values or so-called ecosystems services (e.g., Constanza et al., 2017; Daily, 1997) that such areas provide and which have been theorized elsewhere as 'fourth nature' contributing to developing regenerative natural habitats with rich biodiversity (Franzen, 2000; Landscape Architecture Association, n.d.; Sheppard, 2011). Green and open spaces, such as public parks which contribute to social cohesion and offer leisure opportunities can be conceived as a subset of $\mathrm{Gl}$, whereby $\mathrm{Gl}$ is the overarching "term to describe the network of natural and semi-natural features within and between our towns and cities...rang[ing] in scale from street trees, green roofs and private gardens to parks, rivers and woodlands" (UK Green Building Council, 2015, p. 2). There is a clear notion that ecosystems approaches are required in urban settings (e.g., Chatzimentor, Apostolopoulou, \& Mazaris, 2020) but, reconciling traditional land management perspectives with such ecological imperatives is a challenge for the planning profession which requires new working approaches and skills (Lennon et al., 2016).

An expanding list of studies on $\mathrm{Gl}$ cover issues from finding a common definition, cost-benefit calculations of using green over grey infrastructure (e.g., Environmental Protection Agency, 2014) to exploring policy implications. There is considerable agreement that green infrastructure is multi-scalar and multifunctional. Connecting and re-connecting fragmented green spaces and corridors and ensuring that these spaces can contribute to a variety of different ecosystems services requires multiple actors to collaborate across sectoral and administrative boundaries (Hansmann et al., 2016; Lennon et al., 2016; Mayer et al., 2012). Moreover, it requires political support, funding, and scientific and technical knowledge as well as interdisciplinary and long-term thinking with a considerable need to coordinate activities of different professions and stakeholders. The need for a complex set of skills, knowledge and understanding around $\mathrm{Gl}$ is now increasingly being acknowledged. Research identified limited skills and capacities to effectively and holistically 
assess the quality of green infrastructure (Calvert et al., 2018), to overcome silo mentalities and operationalise Gl approaches on the ground (Lennon, et al., 2016) and a lack of understanding decision-making processes that may enhance $\mathrm{GI}$ via planning instruments and spatial policy (Cowell \& Lennon, 2014). Mell (2019) and The Green Surge (2017) identified knowledge gaps in understanding geographical variability of $\mathrm{Gl}$ effectiveness and stakeholder facilitation skills.

To conclude, Gl planning is more complex than traditional 19th and 20th century green open space planning. A linear history of garden city planning via green belts to green infrastructure is certainly not obvious (Wright, 2011); rather GI planning is intrinsically linked to actively transforming cities and regions to 'greener' and less wasteful, regenerative places via smart, multifunctional design. The question arises, therefore: How can planners acquire the necessary competencies and skills to effectively instigate and steer GI planning? The next section investigates educational offers and whether these have kept pace with the conceptual developments, given that classical coverage of open space planning will unlikely do justice to the complexity associated with GI planning, policies, and implementation.

\section{Educational Provisions for Green Infrastructure Knowledge Development}

Professional knowledge and skills development for planning can be divided into 'initial' or formal education at university followed by continued professional development (e.g., Frank, 2020). This holds true for the majority of planners although increasingly different pathways into the profession emerge. The content of higher education curricula and those that typify land use and design are influenced by a mix of professional body and/or government guidance, practice demands, students, and academic research (Wiśniewska, 2011, p. 66). In an ideal setting, academic research, and professional practice feed off and influence each other (Calderhead, 1989). And, while accreditation guidance of major planning bodies tends to remain at more abstract and general levels (Akkreditierungsverbund für Studiengänge der Architektur und Planung, 2014; Planning Accreditation Board, 2017; Royal Town Planning Institute, 2015), the guidelines stipulate planning graduates acquire knowledge and skills in sustainable development. This in turn can serve as an implicit argument for the inclusion of GI skills and knowledge given the wide-ranging potential of GI to contribute to sustainability. Furthermore, given the government and professional body reports emphasising the importance of GI knowledge, one could expect that academics have begun to embed GI knowledge if not as programme specialisation, or free-standing modules then at least as a concept within relevant modules, e.g., on sustainable urban development. One also would expect continued professional development provision to cover the topic.
Assessing educational provision is notoriously difficult (Frank et al., 2014; UN Habitat, 2009). While at the continued professional development level, professional bodies' training calendars provide an overview, this may be complemented by a range of ad hoc events by independent providers that may accrue continued professional development credits but which are not listed in a way that can be interrogated easily. In higher education, programmes, modules, and their contents change regularly and there is no centralised database. Looking globally, issues around English translation, differing traditions and naming conventions inevitably mean that relevant provision remains hidden. Notwithstanding these constraints, we felt even a preliminary exploration of $\mathrm{Gl}$ training and education provisions would be valuable. Data was collected with a three-pronged approach: (a) looking at continued professional development by canvassing the training offers of commercial providers and professional bodies for 2019/2020, (b) conducting Internet searches for higher education degree offers (credit-bearing certificates/Undergraduate/Postgraduate degrees), and (c) reviewing teaching provision (at module level) for GI at institutional level. Due to the exploratory nature of the study we do not claim to have captured education and training provision comprehensively. For example, for (a) and (c) we focused on the UK and North America-as researching such information requires a somewhat detailed understanding of professional body structures, traditions in terminology use and higher education systems. Other English language provision of continued professional development or in higher education programmes in Northern Ireland, Australia/New Zealand, in Scandinavia or the Netherlands are therefore largely not captured in this study. For (b) a global Internet search was used and to retain the focus of the study a clearly defined set of terms was used (see Table 1). It is acknowledged that results are very likely underreporting activities.

\subsection{Gl in Continued Professional Development Provision}

In the UK, opportunities on green infrastructure training for planners tend to be covered as part of green belt planning, residential development and planning for climate change mitigation and adaptation, and flood management via short webinars, full and half-day seminars as indicated by the Royal Town Planning Institute's, the Town and Country Planning Association's, or the Landscape Institute's published calendars (on average 1-2 events/month). Similar training events exist for planners in the US through the Environmental Protection Agency and the American Planning Association (n.d.), although there is perhaps a greater focus on water management issues. A report (Emmett Environmental Law \& Policy Clinic and the Environmental Policy Initiative, 2014, p. 15) examining professional certification options for GI professionals across the US revealed a high level of 
specialisation both geographically (single state or county) and technologically (e.g., rainwater harvesting, or storm water inspection and management) leading the authors to call for governments to drive development of GI standards and deployment of GI through regulatory tools and potentially run certification programmes (Emmett Environmental Law \& Policy Clinic and the Environmental Policy Initiative, 2014, p. 28). In Canada, the Gaia College and Royal Roads University offer a 12-week course on Living Green Infrastructure geared toward:

Planners, policy makers and developers to provide knowledge and tools to assist professionals and practitioners in attaining a proficient level of competence in living green infrastructure, and for implementing these technologies and best management practices throughout the planning, constructing and maintenance phase of land development. (Royal Roads University, n.d.)

The course is approved for continued professional development credits for a range of landscape professionals to maintain certifications and contributes to the Advanced Diploma in Organic Land Care awarded by the Gaia College (Gaia College, n.d.). It should be noted that other association such as, for example, the Forestry commission, or civil engineering societies or nature conser- vation groups also might provide continued professional development. It is worth noting, though, that a professional requirement for continued professional development credits might reinforce professional silos and limit practical choices of where training is sought.

\subsection{Gl in Initial Spatial Planning Education}

Looking at Bachelor or Master programmes with a focus or specialisation in green infrastructure, a Google search for "'degree program*' AND 'green infrastructure'" was conducted (13 December 2019) in English, whereby the asterisk functioned as wild card to include variations of the relevant word. This unearthed relatively few results (Table 1). One degree with a specialisation and a certificate each were found in Europe, Australia, and the UK, and three in the US. While the table shows all results from the focussed search, this is likely a considerable undercount. It is interesting that two of the Masters, the MSc at the Erasmus University (the Netherlands) and the Master of Biological and Agricultural Engineering (North Carolina State University) adopt a rather technical interpretation of GI. This emphasises the diversity of GI interpretations, an assimilation of the concepts into different professional realms and in turn a need for better transdisciplinary understanding. The widespread absence of ' $\mathrm{Gl}$ ' in programme titles can be interpreted in at least two

Table 1. Higher education degrees/certificates focusing on Gl education.

\begin{tabular}{lll}
\hline Programme name & Institution & Unique selling point \\
\hline Certificate in Green & University of & "The Graduate Certificate in Green Infrastructure...will teach \\
Infrastructure & Melbourne, Australia & you how to use vegetation to improve urban environments for \\
& & their residents" (University of Melbourne, 2020).
\end{tabular}

Master of Biological and Agricultural Engineering

North Carolina State University, NC

Sustainable Environmental Systems MSc

Pratt Institute, NY

MSc Infrastructure and Green Cities

Urban Planning MSc with Green infrastructure and Landscape planning pathway

Master of Urban and Regional Planning
Erasmus University, Rotterdam, the Netherlands

Newcastle University, UK

University of Colorado at Denver, CO
"Interested in low impact design? Go green and use your science and math skills for the greater good. Build a career in green infrastructure" (North Carolina State University, 2020).

"Pratt's Sustainable Environmental Systems program offers a studio in which students gain skills to design green infrastructure in a variety of settings" (Pratt Institute, 2020).

The Infrastructure and Green Cities programme is a specialisation track within the MSc in Urban Management and Development. Key topics include green transport and infrastructure (including drainage).

Green Infrastructure (GI) is the development of solutions to address the increasing human impact on the environment. Gl...can enhance, restore or create landscapes with spaces and linkages for both human and natural systems. You will gain an understanding of: a) the legal framework of $\mathrm{Gl}$ and b) engagement with local communities.

One focus/specialism explores issues like air quality, water supply, habitat fragmentation, green infrastructure, parks, energy consumption, and transportation equity. 
ways: GI might be seen still as something very narrow and specialist and thus unlikely to attract large student numbers, or Gl is conceived as an integral part of another built environment or engineering profession therefore only to be covered in shared or optional provisions and pathways.

\subsection{GI Provision as Part of Spatial Planning Programmes}

Gaining insight into subprogramme level content is challenging as within a programme, module content can and is often updated without changing the module title to avoid administrative work. In some cases, planning educators even have been dissuaded from using $\mathrm{Gl}$ in module titles by their departments as the term 'infrastructure' could be (wrongly) associated with engineering works which were deemed inappropriate in a planning education context (Greve, 2017).

For this aspect of the study, different methods traditionally used to gain insights into teaching content were employed. For example, we examined accreditation documentation where accessible and surveyed instructors including soliciting syllabus and reading lists. These methods will generally provide accurate information and detail. However, the effectiveness of these method relies on trust and works best if targeted directly to relevant scholars or if managed via an umbrella organization towards which there is a feeling of responsibility (e.g., accrediting body) in a narrow and well-defined field. GI knowledge, however, is interdisciplinary and there are in theory, at least, many different disciplines in universities that could be covering GI topics and which students of planning could access. To gain a more comprehensive overview of GI teaching, therefore, a wider range of departments would need to be surveyed. Here a curriculum assessment tool, which uses a computerised analysis of key words/phrases in module titles and descriptions (e.g., Lozano \& Peattie, 2011) could be employed. Such an approach offers efficiencies across a larger set of disciplines but requires access to a searchable database of module descriptions. For ambiguous, and broad concepts with different interpretations, the method might lead to less robust results than a targeted survey.

As access to a 2017 module database was granted at Cardiff University, this approach was used searching of all module titles and descriptions from the departments of Architecture, Geography and Planning, Biosciences, Business School, Social Sciences, Engineering, and Earth Sciences using Boolean search combinations of two and three terms. The results were quite meagre (Table 2) with only two modules in Architecture showing matches for two keywords and 15 matches for two keywords in Geography and Planning and two modules with a match for all three terms. All other departments only showed results for single keywords. Selected follow-up interviews and reflections by instructors of identified modules led to a better understanding of the meaning attributed to $\mathrm{Gl}$, and how much of the teaching was focused on $\mathrm{Gl}$ and what aspects might be covered (e.g. design aspects, or policy). This revealed first that lacking a clear strategic steer or need, through accreditation requirements, individuals had little incentive to make major changes in module content. Secondly, it revealed a wide range of interpretations with one lecturer (L1) defining $\mathrm{Gl}$ as the necessary infrastructure to enable and support alternative 'green' modes of transportation such as walking or cycling, and another relating it to water management issues and "infrastructure of [the] built and ecological environment" (L3).

Using more standard survey methods (via Internet searches and interviewing scholars) looking at spatial/urban/regional planning degrees programmes in the UK, we found the following modules at Undergraduate or Postgraduate level with explicit titles incorporating GI: at the University of Manchester students of the BSC Planning and Environmental Management have access to a module on Green Infrastructure and Sustainable Cities, likewise the University of Liverpool offers an optional module on Green Infrastructure Planning for planning related degrees (BA in Geography and Planning/Urban Planning and integrated MA in Urban Planning). At the University of Sheffield, a module on Health, Wellbeing and the Built Environment includes contributions of GI to well-being. Other UK institutions offering Royal Town Planning Institute accredited planning degrees do offer as part of undergraduate and MAs degrees, modules on sustainable and healthy cities and it is fair to assume that $\mathrm{Gl}$ will be touched upon but it is not clear what proportion of the module time will be dedicated to Gl design, governance, and implementation or policy and what scales are being looked at. At University College London the UG planning programme has a required module on Green Futures which will cover also green infrastructure, however interestingly, their MA in Sustainable Urbanism does not list any module titles containing green infrastructure. In contrast, at Kingston University, the Landscape and Urbanism MA covers not only Green and Blue Infrastructures but also associat-

Table 2. 2017 Module catalogue key word search results at Cardiff University.

\begin{tabular}{lcr}
\hline Keywords & Architecture & Geography \& Planning \\
\hline Green + Urban & 2 & 15 \\
Green + Infrastructure & 0 & 2 \\
Urban + Infrastructure & 0 & 2 \\
Green + Urban + Infrastructure & 0 & 2 \\
\hline
\end{tabular}


ed topics of "wellbeing...climate change, biodiversity" (Kingston University, 2020).

Among US-based planning programmes, the inclusion of Gl courses or a component of a course dealing with broader subject matters are similarly limited. Provision seems most prevalent when there is a joint relationship between landscape architecture and planning. For instance, the University of Massachusetts, Amherst includes these two disciplines in the Department of Landscape Architecture and Planning. A jointly offered course, LA/RP 582 Landscape and Green Urbanism: Theory and Practice, links together GI, sustainability and resilience within the broader frame of green urbanism. At the University of Virginia, a course entitled Green Cities/Green Sites, and Green Lands explores the implementation of $\mathrm{Gl}$ at different scales in Virginia communities. The course "assesses the existing 'green infrastructure' of counties in Virginia and...students will use the existing county comprehensive plan to create effective strategies for implementation of goals related to conserving open space and creating livable communities" (Firehock, 2007, p. 13). At the University of Florida, a course on Environmental Land Use Planning and Management requires students to assess local plans for their level of ecological integrity and how they embrace green infrastructure approaches (URP 6421 Syllabus 2019). The landscape architecture programme in Harvard University's Graduate School of Design, offers a course, Green Infrastructure in the Non-Formal City, that incorporates perspectives on strategies to manage sewerage, stormwater, potable water, waste and energy in extra-legal settlements, particularly in the global South while in the University of California Los Angeles Department of Urban Planning, a course entitled Green Urbanism: The Building Blocks for Creating Sustainable Places examines GI drawing extensively upon Los Angeles and other California experiences in advancing sustainability through green interventions. By contrast, courses in green infrastructure in the Department of Urban Planning at Texas A\&M, focus on GI and human health at the intersection of planning and design. This is accomplished by incorporating an ecological approach in existing offerings, such as an interdisciplinary course, Planning Healthy Communities, which show how GI is an integral part of the relationship of health, planning and design and how the dynamics of this relationship shapes our communities. Jane Futrell Winslow (personal communication, December 29, 2019) stated that there has been also a proposal for a standalone GI course, Green Cities, Healthy Cities, which would offer an even more intensive coverage of the topic. In the University of Pennsylvania's city and regional planning programme, two courses incorporate GI, one being Sustainability and Environmental Planning, and the other, Preserving Agricultural Land (T. Daniels, personal communication, December 30, 2019). Both draw upon the instructor's own research in green infrastructure but also expose students to the growing literature in the field.

\section{Discussion}

The review of education opportunities for spatial planners regarding $\mathrm{Gl}$ knowledge and skills reveals a mixed and changing picture. A Google search of "'green infrastructure' AND 'planning education"' shows a growth in hits from 15,900 (August 6, 2017, 12:30am UK time) to 37,900 (July 24, 2020, 17:30 UK time). "'Green infrastructure' AND 'urban planning program*"' and "'green infrastructure' AND 'urban planning course"' resulted in 9,430 (2017) and 22,300 (2020) and 1,530 (2017) and 2,750 (2020) hits respectively. The term "'green infrastructure' AND 'planning education curricul*"' yielded merely 2 results on November 22, 2017, but 2,400 on July 24, 2020. This suggests that $\mathrm{Gl}$ education options are increasingly provided and written about as part of planning but also of other disciplines. While $\mathrm{GI}$ is seen as multifunctional, education and research appears to be centred around thematic clusters such as biodiversity, ecosystems services or green spaces/corridors and forests at the municipal level (e.g., Chatzimentor et al., 2020) at least in the European context. Table 1 corroborates that $\mathrm{Gl}$ is embraced by a range of professions and disciplines in higher education.

Opportunities for continued professional development as well as a set of programmes in higher education exist that are geared to enhance Gl skills and knowledge. Given an identified need to bolster interdisciplinary working when operationalising a GI approach, the effectiveness of practice sessions by a single professional body may be limited. Other, interactive approaches such as those proposed by The Green Surge (2017), or Lennon et al. (2016) featuring gaming and interactive workshops that offer nonthreatening learning environments for interdisciplinary professional groups may have deeper impacts. Both examples derive from research projects. Instincts to protect professional boundaries and turf will likely prevent traditional professional associations and societies-be it urban planners, landscape architects or engineers-from offering such activities in their standard continued professional development programmes.

Reviewing results for planning education in higher education suggest that individual scholars championing the topic as well as a linkage between planning and landscape architecture that characterizes some US programmes, or environmental sciences (in the UK) are likely factors supporting current offerings. Nevertheless, GI is (still) not what might be considered a 'core' competency in planning education in either country despite an ever more urgent demand for $\mathrm{Gl}$ integration in urban space. With few exceptions GI is only an optional topic amongst others in planning education related to environmental issues. This is a precarious situation as is illustrated by the Green Infrastructure Design-Built Studio at the Pratt Institute in New York City. The studio ran every summer from 2012 to 2016 as part of the MS Sustainable Environmental Systems but has ceased probably due to a 
change in instructors or because on campus built-design opportunities have dried up.

Green infrastructure can be viewed as one dimension of a wider gamut of measures that support planning and policy for sustainable urban land management (Hansen et al., 2017) which typically is included in most accreditation criteria for urban, regional or spatial planning degrees (e.g., Planning Accreditation Board, 2017; Royal Town Planning Institute, 2015). As a result, students are exposed to concepts that support sustainable development such as walkability, mixed-use zoning, as well as aspects of green infrastructure. As time on degree programmes is limited, programme leaders are careful not to introduce a new module or speciality each time a seemingly relevant topic appears. In our own position as researchers on $\mathrm{Gl}$ and educators we have reflected upon how GI might be incorporated into planning education and recognized limits on our ability to innovate that arises from real and perceived constraints including: (a) teaching on 'core' modules with prescribed learning outcomes by the accreditation body curbing the flexibility to introduce new content; (b) managing curriculum time: with a fixed amount of credits difficult decisions arise on what is essential to retain and what might reasonably be replaced. The challenge of refreshing module content can be exacerbated in team teaching situations when colleagues insist on retaining their contribution; (c) managing workload when it can (most likely is) more straightforward to update existing material rather than replace it with new material; and (d) catering to student expectations; if a module is well received it is tempting to be risk averse and reproduce it rather than introduce change.

Scholar-driven teaching innovations on GI, therefore, are likely to remain small-scale, ad hoc and often hidden from the gaze of others, including the host institution as many of the examples demonstrate where GI is part of the teaching or used in assignments but the module title does not indicate any GI content specifically. Dynamics could be changed via external pressures from relevant stakeholders such as practitioners or accreditation requirements-entities that tend to play a role in shaping education content through curriculum reviews and audits. Private sector interests in the planning realm are important for GI in two ways: On the one side they can provide guest lectures, and continued professional development and on the other they make knowledge demands about the types of training that they think are valuable for professional planners. In an increasingly neoliberal education system course content is often judged whether it is fit for purpose by recourse to standards and measures. Employability statistics are highly valued by those who seek to promote courses and distinguish them from competitors. More reflective or challenging perspectives on planning that are valued in academia may be less valued by the planning community. GI seems to fall between the two stools: there is not an obvious market demand for planners to be trained in $\mathrm{GI}-$ although this may be changing given the recent calls for more quality open space in urbanized areas (Royal Town Planning Institute, 2020) or critique of failures to operationalize GI approaches effectively (Cowell \& Lennon, 2014; Lennon et al., 2016; Meerow \& Newell, 2017)—nor does $\mathrm{GI}$ with its links to practice readily offer itself for theoretical critique. Wiśniewska (2011) suggested that some topics are unlikely driven by the profession or the market and it may fall to governments and academics to lead on inserting challenging and critical elements into curricula so as to ensure that students are introduced to progressive new knowledge areas and concepts.

We know from experience that innovations also have unintended side effects and as such it is vitally important to scrutinize them thoroughly. Planners need a solid grounding of what is GI, its principles, benefits, drawbacks, its planning, design, implementation, and management/maintenance. And while continued professional development opportunities exist, we feel an earlier exposure of future planners to the subject would assist the imperative ecological shift promoted by so many professions. Thus, at a minimum planning education should cover basic theoretical debates as well as practical issues via a lecture course and studio on, for example, place development or strategic planning. Additionally, curricula should include options, ideally in collaboration with other disciplines and departments emphasizing the need to work across disciplinary boundaries to build on synergies and other knowledges. Provision of such modules are increasingly emerging in university course catalogues; they include topics such as: (a) green infrastructure in Non-Formal Cities (development studies/politics); (b) green infrastructure and water management (with engineering); (c) green infrastructure and health (with public health/medical sciences); (d) urban food production and sustainability/circular economy (economy/engineering); (e) green infrastructure and biodiversity (with Biology); (f) green infrastructure for recreation (with sports/recreation studies); and (g) green infrastructure and buildings (with architecture).

\section{Summary and Recommendations}

Four decades from first introducing the concept of $\mathrm{Gl}$ in spatial planning literature (e.g., Hauserman, 1995; Walmsley, 1995), a proliferation of reports and guidance on the subject have soundly established a central role for $\mathrm{Gl}$ in planning for sustainable cities and regions (e.g., American Planning Association, 2007; Environmental Protection Agency, 2014; Royal Town Planning Institute, 2013; UN Habitat, 2017). The 2020 health pandemic caused by Covid-19 has, if anything, corroborated the value and necessity of planning and implementing $\mathrm{Gl}$ and quality open spaces in cities for the health and well-being of inhabitants (Royal Town Planning Institute, 2020).

Considering this, our aim was to explore what types of GI knowledge planners may require and by whom and how this knowledge may be provided and disseminated. 
And, while Wiśniewska (2011) amongst others alluded that the development of GI and its link to sustainability and health appears in part to be a re-packaging of previously used concepts of green open spaces and multifunctionality in planning to fit with the rhetoric of sustainable development, scholars also suggested that GI is far more complex (Lennon et al., 2016) than traditional green space planning and requires particular skill sets for its successful implementation including interdisciplinary working, enacting multi-institutional governance and multidisciplinary stakeholder facilitation.

Preliminary explorations into the provision of $\mathrm{GI}$ knowledge and skills within higher education planning degree courses indicate that the concept's varied interpretation combined with abstract accreditation guidelines and conflictual value systems and perceptions undermine more explicit and systematic coverage of $\mathrm{GI}$ issues, particularly, in terms of policy and theoretical foundations. It may be astounding that teaching and learning of and about $\mathrm{Gl}$ seems not to have gained a more prominent role in planning curricula to date. Yet, given Nasr and Komisar's (2012) findings that integration of an interdisciplinary field into design and planning education (referring to food planning) is challenging, it should not come as a surprise that GI has not been able to establish itself more firmly as a core planning theme.

Continued professional development courses are offered covering mostly practical issues of plan implementation in short 1 h to 1-day long sessions which are unlikely to address GI critically or to promote interdisciplinary GI thinking. While research has explored impactful training in this area using gaming and interactive interdisciplinary workshops, additional work is needed to explore how such activities could be made attractive across the diverse professions and disciplines involved in Gl implementation.

Given the growing urgency to reconsider the humannature relationship, it is vital that built environment professionals gain comprehensive skills and understanding of GI planning issues. The fragmented and ad hoc provision at present will not suffice; instead, a ramping up of capacity building activities across a range of disciplines including spatial and urban planning is needed. A thorough introduction of the link between GI concepts and planning at initial education stages would be in our opinion advantageous to offer a grounding for future planning professionals. This could effectively complement and bolster efforts to upskill and train planning practitioners in $\mathrm{Gl}$ thinking through continued professional development.

While Wiśniewska (2011) suggested that practice may not keen to embrace and therefore push novel concepts for inclusion in education, the possibility, importance and success of government intervention in shaping educational agendas has been highlighted by Emmett Environmental Law \& Policy Clinic and the Environmental Policy Initiative (2014). As such more formal inclusion of $\mathrm{Gl}$ issues in the planning curriculum might best be supported by requirements from accrediting bodies but may also require concerted action from academia in terms of bolder integration of $\mathrm{GI}$ research in teaching. The increasing rhetoric by politicians, and city makers around biophilic cities and bringing nature back into the built environment should help make a case to integrate GI into planning programmes. To promote this agenda, it is suggested that planning educators: (a) investigate on a national or continental basis Gl skills and knowledge needs; (b) lobby professional bodies, governments and agencies to include $\mathrm{Gl}$ in accreditation guidance; (c) create interdisciplinary communities of practice to exchange experiences in course design and delivery; (d) collaborate with researchers that conduct research on $\mathrm{Gl}$, including developing interdisciplinary frameworks and theoretical aspects; and (e) create specialisation streams/certificates in GI to embed the topic as core planning theme alongside other progressive ones such as climate change and strengthen links to other fields such as health/biology/engineering.

\section{Acknowledgments}

The authors are grateful for a 2-month Cardiff University Research Opportunity Placement for Joanna Pogorzelska who provided data collection and research support.

\section{Conflict of Interests}

The authors declare no conflict of interests.

\section{References}

Ahern, J. (1995). Greenways as planning strategy. Landscape and Urban Planning, 33, 131-155.

Akkreditierungsverbund für Studiengänge der Architektur und Planung. (2014). Criteria for the accreditation of courses of study in urban planning/spatial planning (4th edition). Berlin: Akkreditierungsverbund für Studiengänge der Architektur und Planung. Retrieved from https://www.asap-akkreditierung. de/images/dokumente/de/manual_urban_spatial_planning_english_version-2014_.pdf

American Planning Association. (2007). How cities use parks for...Green Infrastructure. American Planning Association. Retrieved from https://www. planning.org/cityparks/briefingpapers/ greeninfrastructure.htm

American Planning Association. (n.d.). Educational events. APA Events. Retrieved from https://www. planning.org/events/?keyword=green+infrastructure

American Rivers. (n.d.). What is green infrastructure? American Rivers. Retrieved from https://www. americanrivers.org/threats-solutions/clean-water/ green-infrastructure/what-is-green-infrastructure

Australian Institute of Landscape Architects. (2015). 15 year infrastructure plan for Australia. Outdoor Design. Retrieved from http://www.outdoor 
design.com.au/news-info/Green-InfrastructurePlan-for-Australia/3904.htm

Benedict, M. A., \& McMahon, E. T. (2001). Green infrastructure: Smart conservation for the $21^{\text {st }}$ century. Washington, DC: Sprawl Watch Clearinghouse. Retrieved from http://www.sprawlwatch.org/ greeninfrastructure.pdf

Benedict, M. A., \& McMahon, E. T. (2002). Green infrastructure: Smart conservation for the 21st century. Renewable Resources Journal, 20(3), 12-17.

Benedict, M. A., \& McMahon, E. T. (2006). Green infrastructure: Linking landscapes and communities. Washington DC: Island Press.

Calderhead, J. (1989). Reflective teaching and teacher education. Teaching and Teacher Education, 5(1), 43-51.

Calvert, T., Sinnet, D., Smith, N., Jerome, G., Burgess, S., \& King, L. (2018). Setting the standard for green infrastructure: The need for, and features of, a benchmark in England. Planning Practice \& Research, 33(5), 558-573.

Chatzimentor, A., Apostolopoulou, E., \& Mazaris, A. D. (2020). A review of green infrastructure research in Europe: Challenges and opportunities. Landscape and Urban Planning, 198. https://doi.org/10.1016/ j.landurbplan.2020.103775

Chaudhary, S., McGregor, A., Houston, D., \& Chettri, N. (2015). The evolution of ecosystem services: A time series and discourse-centred analysis. Environmental Science \& Policy, 54, 25-34.

Constanza, R., de Groot, R., Braat, L., Kubiszewski, I., Fioramonti, L., Sutton, P., . . . Grasso, M. (2017). Twenty years of ecosystem services: How far have we come and how far do we still need to go? Ecosystem Services, 28, 1-16.

Cowell, R., \& Lennon, M. (2014). The utilisation of environmental knowledge in land-use planning: Drawing lessons for an ecosystem services approach. Environment and Planning C: Government and Policy, 32, 263-282.

Daily, G. C. (1997). Nature's services: Societal dependence on natural ecosystems. Washington, DC: Island Press.

Emmett Environmental Law, \& Policy Clinic and the Environmental Policy Initiative. (2014). Certifications for green infrastructure professionals: The current state, recommended best practices and what governments can do to help. Cambridge, MA: Harvard Law School. Retrieved from http://environment. law.harvard.edu/wp-content/uploads/2015/08/ certifications-green-infrastructure-professionals.pdf

Environmental Protection Agency. (2014). Enhancing sustainable communities with green infrastructure (Environmental Protection Agency 100-R-14-006). Washington, DC: Environmental Protection Agency. Retrieved from https://www.epa.gov/sites/ production/files/2016-08/documents/greeninfrastructure.pdf

European Commission. (2016). The forms and func- tions of green infrastructure. Brussels: European Commission.

European Commission. (2020). Ecosystem services and green infrastructure. European Commission. Retrieved from https://ec.europa.eu/environment/ nature/ecosystems/index_en.htm

Firehock, K. E. (2007). Green infrastructure planning: College curriculum guide. Charlottesville, VA: The Green Infrastructure Center Inc. Retrieved from http://www.gicinc.org/Curriculum\%20Guide\% 20for\%20Green\%20Infrastructure\%20Planning.pdf

Frank, A. I. (2020). Education and demonstration of professional competence. In N. Green Leigh, S. P. French, S. Guhathakurta, \& B. Stiftel (Eds.), Routledge handbook of international planning education (1st ed., pp. 12-27). New York, NY and Abingdon: Routledge.

Frank, A. I., Mironowicz, I., Lourenco, J., Franchini, T., Ache, P., Finka, M., . . Grams, A. (2014). Educating planners in Europe: A review of $21^{\text {st }}$ century study programmes. Progress in Planning, 91, 30-94.

Franzen, B. (2000). Die vierte Natur: Gärten in der zeitgenössischen Kunst [The fourth Nature: Gardens in contemporary Art]. Cologne: Verlag der Buchhandlung König.

Gaia College. (n.d.). Living green infrastructure online: Credits. Gaia College. Retrieved from https:// www.gaiacollege.ca/living-green-infrastructureonline.html\#credits

Greve, A. (2017). Climate action planning and community planning studios: Student Learning outcomes and lessons for curriculum. Paper presented at the Association of Collegiate Schools of Planning Conference 2017, Denver, CO.

Hansen, R., Rall, E., Chapman, E., Rolf, W., \& Pauleit, S. (Eds.). (2017). Urban green infrastructure planning: A guide for practitioners. GREEN SURGE. Retrieved from http://greensurge.eu/working-packages/wp5

Hansmann, R., Whitehead, I., Krajter Ostoić, S., Živojinović, I., Stojanovska, M., Jones, N., . . . Barstad, J. (2016). Partnerships for urban forestry and green infrastructure delivering services to people and the environment: A review on what they are and aim to achieve. South-East Europen Forestry, 7(1), 9-19.

Hauserman, J. (1995). Green infrastructure and landscape architects help design a statewide greenway network in Florida. Landscape Architecture, 85, 58-61.

Kingston University. (2020). Landscape and Urbanism MA. Kingston University. Retrieved from https:// www.kingston.ac.uk/postgraduate/courses/ landscape-urbanism-ma

Landscape Architecture Association. (n.d.). Biodiversity and fourth nature. Landscape Architecture Association. Retrieved from http://www.landscape architecture.org.uk/theory-of-landscapearchitecture/biodiversity-the-sixth-extinctionand-the-fourth-nature

Lennon, M., Scott, M., Collier, M., \& Foley, K. (2016). 
Developing green infrastructure 'thinking': Devising and applying an interactive group-based methodology for practitioners. Journal of Environmental Planning and Management, 59(5), 843-865.

Liu, W., Chen, W., \& Peng, C. (2014). Assessing the effectiveness of green infrastructures on urban flooding reduction: A community scale study. Ecological Modelling, 291, 6-14.

Lozano, R., \& Peattie, K. (2011). Assessing Cardiff University's curricula contribution to sustainable development using the STAUNCH(RTM) system. Journal of Education for Sustainable Development, 5(1), 115-128.

Mayer, A. L., Shuster, W. D., Beaulieu, J. J., Hopton, M. E., Rhea, L. K., Roy, A. H., \& Thurston, H. W. (2012). Building green infrastructure via citizen participation: A six-year study in the Shepherd Creek (Ohio). Environmental Practice, 14, 57-67.

MEA. (2005). Ecosystems and human wellbeing. Washington DC: Island Press.

Meerow, S., \& Newell, J. P. (2017). Spatial planning for multifunctional green infrastructure: Growing resilience in Detroit. Landscape and Urban Planning, 159, 62-75.

Mell, I. (2019). Green infrastructure planning: Reintegrating landscape in urban planning. London: Lund Humphries.

Nasr, J., \& Komisar, J. (2012). The integration of food and agriculture into urban planning and design practices. In A. Viljoen \& J. Wiskerke (Eds.), Sustainable food planning (pp. 47-58). Wageningen: Wageningen Academic Publishers.

Natural England. (2009). Green infrastructure guidance. Worcester: Natural England and Land Use Consultants.

North Carolina State University. (2020). Masters of Biological and Agricultural Engineering. North Carolina State University. Retrieved from https://online.bae. ncsu.edu/green-infrastructure

Olmsted, F. L. (1870). Public parks and the enlargement of towns. Cambridge: Riverside Press.

Planning Accreditation Board. (2017). Planning accreditation board accreditation standards and criteria, approved March 3, 2017. Chicago, IL: Planning Accreditation Board. Retrieved from. file://C:/Users/aifra/Downloads/2017Standards.pdf

Potschin, M., Haines-Young, R., Fish, R., \& Kerry Turner, R. (2016). Routledge handbook of ecosystem services (1st ed.). New York, NY and Abingdon: Routledge.

Pratt Institute. (2020). Green Infrastructure. Pratt Institute. Retrieved from https://www.pratt.edu/ academics/architecture/sustainable-environmentalsystems/green-infrastructure

Royal Roads University. (n.d.). Living green infrastructure. Royal Roads University. Retrieved from https:// cstudies.royalroads.ca/living-green-infrastructureonline

Royal Town Planning Institute. (2013). Briefing on green infrastructure in the United Kingdom. London: Royal Town Planning Institute.

Royal Town Planning Institute. (2015). Guide to Royal Town Planning Institute accreditation, appendix 3. London: Royal Town Planning Institute. Retrieved from http://www.rtpi.org.uk/media/1593916/rtpi_ guide_to_accreditation_december_2015.pdf

Royal Town Planning Institute. (2020). Plan the world we need: The contribution of planning to a sustainable, resilient and inclusive recovery (Research Paper June 2020). London: Royal Town Planning Institute. Retrieved from https://www.rtpi.org.uk/ research/2020/june/plan-the-world-we-need

Sandström, U. G. (2002). Green infrastructure planning in urban Sweden. Planning Practice \& Research, 17(4), 373-385.

Sheppard, L. (2011). 1-2-3...fourth nature? ParadoXcity Studio Venice. Retrieved from https://pages. shanti.virginia.edu/Venice_11Sp_ALAR/resources/12-3-fourth-nature

Silver, C. (2018). The origins of planning education: Overview. In A. I. Frank \& C. Silver (Eds.), Urban planning education: Beginnings, global movement and future prospects (pp. 11-25). Cham: Springer.

Sinnett, D., Smith, N., \& Burgess, S. (Eds.). (2015). Handbook on green infrastructure. Cheltenham: Edward Elgar.

Stovin, V. R., Jorgensen, A., \& Clayden, A. (2008). Street trees and stormwater management. Arboricultural Journal, 30(4), 297-310.

Swanwick, C., Dunnett, N., \& Woolley, H. (2003). Nature, role and value of green space in towns and cities: An overview. Built Environment, 29(2), 94-106.

The Earth Genome. (2016). GIST: Green infrastructure support tool. The Earth Genome. Retrieved from https://www.earthgenome.org/gist

The Green Surge. (2017). Green infrastructure and urban biodiversity for sustainable urban development and the green economy (Final project report). Luxembourg: CORDIS/Publications Office of the European Union. Retrieved from https://cordis.europa. eu/project/id/603567/reporting

Tzoulas, K., Korpela, K., Venn, S., Yli-Pelkonen, V., Kaźmierczak, A., Niemela, J., \& James, P. (2007). Promoting ecosystem and human health in urban areas using green infrastructure: A literature review. Landscape and Urban Planning, 81, 167-178.

UK Green Building Council. (2015). Demystifying green infrastructure. London: UK Green Building Council. Retrieved from http://www.ukgbc.org/sites/default/ files/Demystifying\%20Green\%20Infrastructure\% 20report\%20FINAL.pdf

UN. (2015). Sustainable development goals. New York, NY: United Nations. Retrieved from https:// www.un.org/sustainabledevelopment/sustainabledevelopment-goals

UN Habitat. (2009). Planning sustainable cities: Global report on human settlements 2009. London: 
Earthscan.

UN Habitat. (2017). New urban agenda. New York, NY: United Nations. Retrieved from http://habitat3.org/ wp-content/uploads/NUA-English.pdf

University of Melbourne. (2020). Graduate certificate in Green Infrastructure. University of Melbourne. Retrieved from https://study.unimelb.edu.au/find/ courses/graduate/graduate-certificate-in-greeninfrastructure

Walmsley, A. (1995). Greenways and the making of urban form. Landscape and Urban Planning, 33, 81-127.

Wiśniewska, M. (2011). A study of the incorporation of green infrastructure into planning courses in UK higher education (Doctoral dissertation). Kingston University, London, UK.

Wright, H. (2011). Understanding green infrastructure: The development of a contested concept in England. Local Environment, 16, 1003-1019.

Zuniga-Teran, A. A., Staddon, C., de Vito, L., Gerlak, A. K., Ward, S., Schoeman, Y., . . . Booth, G. (2020). Challenges of mainstreaming green infrastructure in built environment professions. Journal of Environmental Planning and Management, 63(4), 710-732.

\section{About the Authors}
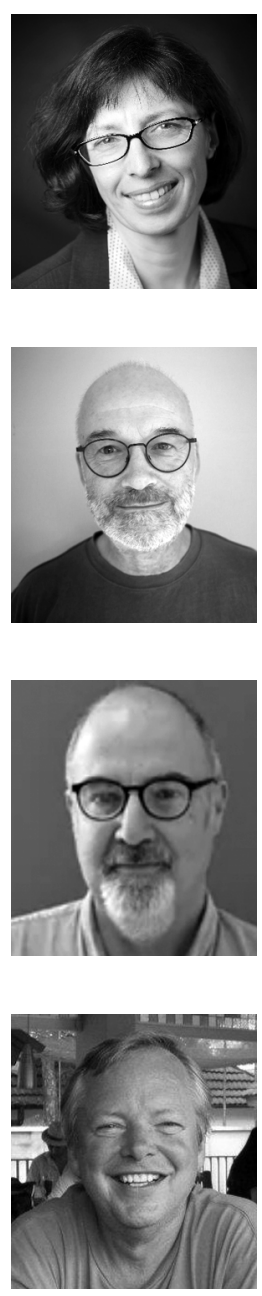

Andrea I. Frank (PhD) is a Teaching Fellow in Planning at the University of Birmingham. Previously, she has held academic appointments at University of Michigan, RWTH Aachen, University of Indonesia, University of Applied Science Stuttgart, Cardiff University, and HafenCity University Hamburg. Awarded Senior Fellow of the Higher Education Academy (UK) in 2014, she has a track record in research on and promoting excellence in planning education and pedagogy. Additional research interests include green infrastructure, public participation and citizen science, urban design, and regional planning.

Andrew Flynn is Professor in Environmental Policy and Planning in the School of Geography and Planning at Cardiff University. His research focusses on three themes: a) changing nature of the local state and how it is increasingly performing multiple environmental functions; b) governance of sustainability and the ways in which sustainability is constructed; c) private interests and standard setting which involves analysing how the private sector interacts with public bodies to produce standards that are, in turn, shaping ideas of the environment and the role of government.

Nick Hacking (PhD) is a Lecturer at the School of Geography and Planning at Cardiff University. His research covers the environmental governance of sustainability transitions in the waste, resources and energy sectors (specifically the 'circular economy' and the 'hydrogen economy') and different pedagogic approaches to teaching such material. Nick's research critiques the delivery of new 'greener' infrastructure via the planning system (e.g., energy-from-waste facilities, biomass energy plants and hydrogen storage projects, for example).

Christopher Silver (PhD, FAICP) is Professor of Urban and Regional Planning, University of Florida. $\mathrm{He}$ is author of Planning the Megacity: Jakarta in the Twentieth Century (Routledge, 2008, 2011) and co-editor (with A. Frank) of Urban Planning Education: Beginnings, Global Movement and Future Prospects (Springer, 2018), and (with R. Freestone and C. Demaziere), Dialogues in Urban and Regional Planning: The Right to the City (Taylor and Francis, 2018). He is the founding editor of the Journal of Planning History. 